Article

\title{
Dangerous Relations in the Arctic Marine Food Web: Interactions between Toxin Producing Pseudo-nitzschia Diatoms and Calanus Copepodites
}

\author{
Sara Harðardóttir ${ }^{1,2, *}$, Marina Pančić ${ }^{1,2}$, Anna Tammilehto ${ }^{1}$, Bernd Krock ${ }^{3}$, \\ Eva Friis Møller ${ }^{4}$, Torkel Gissel Nielsen ${ }^{2}$ and Nina Lundholm ${ }^{1}$
}

1 Natural History Museum of Denmark, University of Copenhagen, Sølvgade 83S, 1307 Copenhagen, Denmark; E-Mails: marina.pancic@snm.ku.dk (M.P.); atammilehto@snm.ku.dk (A.T.); nlundholm@snm.ku.dk (N.L.)

2 National Institute of Aquatic Resources, Technical University of Denmark, Charlottenlund Slot, Jægersborg Allé 1, 2920 Charlottenlund, Denmark; E-Mail: tgin@aqua.dtu.dk

3 Alfred-Wegener-Institut für Polar- und Meeresforschung, Ökologische Chemie, Am Handelshafen 12, 27570 Bremerhaven, Germany; E-Mail: bernd.krock@awi.de

4 Arctic Research Center, Department of Bioscience, Roskilde, Aarhus University, Frederiksborgvej 399, P.O. Box 358, 4000 Roskilde, Denmark; E-Mail: efm@bios.au.dk

* Author to whom correspondence should be addressed; E-Mail: Sara.Hardardottir@snm.ku.dk; Tel.: $+45-35330856$.

Academic Editor: Véronique Martin-Jézéquel

Received: 5 February 2015 / Accepted: 28 May 2015 / Published: 16 June 2015

\begin{abstract}
Diatoms of the genus Pseudo-nitzschia produce domoic acid (DA), a toxin that is vectored in the marine food web, thus causing serious problems for marine organisms and humans. In spite of this, knowledge of interactions between grazing zooplankton and diatoms is restricted. In this study, we examined the interactions between Calanus copepodites and toxin producing Pseudo-nitzschia. The copepodites were fed with different concentrations of toxic $P$. seriata and a strain of $P$. obtusa that previously was tested to be non-toxic. The ingestion rates did not differ among the diets ( $P$. seriata, P. obtusa, a mixture of both species), and they accumulated $6 \%-16 \%$ of ingested DA (up to $420 \mu \mathrm{g}$ per dry weight copepodite). When P. seriata was exposed to the copepodites, either through physical contact with the grazers or separated by a membrane, the toxicity of $P$. seriata increased (up to $3300 \%$ ) suggesting the response to be chemically mediated. The induced response was also triggered when copepodites grazed on another diatom, supporting the hypothesis
\end{abstract}


that the cues originate from the copepodite. Neither $\mathrm{pH}$ nor nutrient concentrations explained the induced DA production. Unexpectedly, P. obtusa also produced DA when exposed to grazing copepodites, thus representing the second reported toxic polar diatom.

Keywords: Calanus copepodites; Pseudo-nitzschia seriata; P. obtusa; grazing; induction; chemical ecology; toxin production; domoic acid

\section{Introduction}

The marine biotoxin domoic acid (DA) causes amnesic shellfish poisoning (ASP) in humans [1,2], and exposure to DA is known to have harmful effects on animals in the marine food web, e.g., sea birds and mammals [3,4]. DA is produced by species of the diatom genera Nitzschia and Pseudo-nitzschia as a secondary metabolite [5,6]. DA accumulates in marine organisms that feed on phytoplankton, e.g., planktivorous fish (such as sardines), bivalves and copepods [7-9], which may then serve as vectors for DA in the food web. Despite the grim effects that DA-producing diatoms have on higher trophic levels, only a few studies have explored the relations between toxic diatoms and their grazers $[10,11]$.

Pseudo-nitzschia is a globally distributed diatom genus, of which many species form extensive blooms. Fourteen of the 39 described species are known to be toxigenic [11]. The first recorded ASP incident in 1987 in Prince Edward Island, Canada [1], resulted in increased research interest, and surveillance programs now monitor concentrations of Pseudo-nitzschia and/or levels of DA in mollusks. These research and monitoring efforts have particularly expanded our knowledge of the ecology, distribution, taxonomy, and toxin-production of Pseudo-nitzschia in temperate, subtropical and tropical areas. The polar regions, however, have received much less attention. No records of a toxigenic Pseudo-nitzschia species exist from the Antarctic and the first, and so far only, record of a toxin-producing diatom in the Arctic is P. seriata [12,13].

Several species of copepods are known to graze on toxic Pseudo-nitzschia. Most studies have not detected any reduction in grazing on toxic versus non-toxic Pseudo-nitzschia [9,14-17]. The only study conducted on arctic copepods, Calanus spp., did not find significant differences in the overall weight-specific ingestion of toxic and non-toxic species in three Calanus species. However, discontinuous grazing rates were detected, indicating that two of the species, C. finmarchicus and $C$. hyperboreus, were temporally affected when fed with toxic P. seriata. This suggests that DA may act as a grazing deterrent against copepods [18]. A similar impact was seen on the grazing pattern in the krill Euphausia pacifica, when grazing on toxic P. multiseries was compared to non-toxic P. pungens [19].

Pseudo-nitzchia seriata increased production of DA when exposed to grazing adult Calanus copepods [20], an effect which may be related to defense against grazing, and the response was found to be chemically mediated. Changes in nutrients (silicate, nitrate, ammonium and phosphate), and changes in $\mathrm{pH}$ levels are known triggers for DA production in Pseudo-nitzschia species [21-23]. However, the few studies that have measured changes in nutrients when investigating induced 
responses in phytoplankton by zooplankton, have not found the nutrients to be the inductive factor [24-27].

In the Arctic, copepods of the genus Calanus dominate the mesozooplankton. Before the phytoplankton spring bloom, the copepods ascend from the depth to feed, reproduce and spawn [28]. After spawning, the adult Calanus copepods descend to the water near the bottom for hibernation [29]. Thereafter, the younger stages are among the most abundant mesozooplankton and are often key grazers during the post bloom period [30,31]. The grazing studies mentioned previously were all performed on adult females. It is not known if the younger stages graze on Pseudo-nitzschia and if they do, whether they are more vulnerable to the toxins. To our knowledge, no other studies have explored the effect of DA on younger stages of copepods and whether they retain DA, neither have their effect on toxin production in phytoplankton been explored.

The aims of the present study were to investigate the interaction between Calanus copepodites and Pseudo-nitzschia, i.e., (1) if copepodites select between Pseudo-nitzschia species of different toxicity or size; (2) if grazing on toxic Pseudo-nitzschia affects grazing rates and/or mortality of the copepodites; (3) if copepodites retain DA; (4) if grazing pressure from the copepodites induces DA production in a toxic ( $P$. seriata) and a non-toxic ( $P$. obtusa) Pseudo-nitzschia species; and (5) if the induced DA production is mediated because of changes in the major inorganic nutrients or $\mathrm{pH}$, or due to waterborne chemical cues from the copepodites.

\section{Results}

\subsection{Temporal Grazing Experiment}

\subsubsection{Toxicity}

At the beginning of the experiment, the copepodites and the $P$. obtusa cells did not contain DA, whereas $P$. seriata cells contained low amounts of DA, $\sim 0.1 \mathrm{pg}$ cell $^{-1}$ (level of detection $=0.003 \mathrm{pg}$ DA cell ${ }^{-1}$ ) (Table 1). Domoic acid cell quotas increased significantly in both $P$. seriata and $P$. obtusa when exposed to grazers, but not in the control without copepodites (Table 1). This is the first report of DA production by $P$. obtusa. $P$. seriata produced more DA than $P$. obtusa per cell ( $t$-test, $P<0.001)$ (Table 1), and also per volume, i.e., considering the larger biovolume of $P$. seriata $\left(\sim 2.2 \times 10^{-3}\right.$ and $\sim 0.5 \times 10^{-3}$ pg DA per $\mu \mathrm{m}^{3}$, for $P$. seriata and $P$. obtusa, respectively) ( $t$-test, $P=0.003$ ). Dissolved DA was not measured. At the end of the experiment, the copepodites retained $0.1 \pm 0.0 \mathrm{ng} \mathrm{DA} \mu \mathrm{g} \mathrm{C}^{-1}$ after grazing on $P$. obtusa, the $P$. obtusa cells produced $0.4 \pm 0.1 \times 10^{-4} \mathrm{ng}$ DA $\mu \mathrm{g} \mathrm{C}^{-1}$. After grazing on $P$. seriata for $39 \mathrm{~h}$, the copepodites retained $0.6 \pm 0.2 \mathrm{ng} \mathrm{DA} \mu \mathrm{g} \mathrm{C}^{-1}$, the $P$. seriata cells produced $1.9 \pm 4.4 \times 10^{-4} \mathrm{ng}$ DA $\mu \mathrm{g} \mathrm{C} \mathrm{C}^{-1}$. DA measured in the copepodites ranged from 8.2 to $69.7 \mathrm{ng}$ DA per individual, with the lowest amount after grazing on P. obtusa and the highest after grazing on $P$. seriata (Mann-Whitney Rank Sum Test, $P=0.03$ ) (Table 1). Of the ingested DA after grazing on P. obtusa, the copepodites retained $6 \%$, and $13 \%-16 \%$ when grazing on $P$. seriata and mixture of both, respectively. 
Table 1. Grazing experiment. Pseudo-nitzschia cell density (cells $\mathrm{mL}^{-1}$ ) and domoic acid (DA) cell quota (pg DA cell ${ }^{-1}$ ) in P. seriata and P. obtusa in treatments and controls. Calanus total ingested (ng DA $\operatorname{cop}^{-1}$ ) and retained DA per copepodite, given in measured DA (ng DA cop ${ }^{-1}$ ), by dry weight ( $\mu$ g DA g DW $\operatorname{cop}^{-1}$ ) and as percent of ingested DA. Results are given as $*=$ significant difference from start to end, and $* *$ for significant difference between control and treatment. LOD $=$ level of detection. (LOD for P. obtusa was $0.001 \mathrm{pg}$ DA cell $\left.{ }^{-1}\right)$.

\begin{tabular}{|c|c|c|c|c|c|c|c|c|}
\hline & \multicolumn{4}{|c|}{ Pseudo-nitzschia } & \multicolumn{4}{|c|}{ Calanus } \\
\hline & \multicolumn{2}{|c|}{ Number of Cells } & \multicolumn{2}{|c|}{ DA Cell Quota } & \multirow{3}{*}{$\begin{array}{c}\text { Ingested DA } \\
(\text { ng DA } \\
\left.\operatorname{cop}^{-1}\right)\end{array}$} & \multirow{3}{*}{$\begin{array}{c}\text { Retained DA } \\
(\text { ng DA } \\
\left.\operatorname{cop}^{-1}\right)\end{array}$} & \multirow{3}{*}{$\begin{array}{c}(\mu \mathrm{g} \text { DA g } \\
\left.\text { DW } \operatorname{cop}^{-1}\right)\end{array}$} & \multirow{3}{*}{$\begin{array}{c}\text { \% of } \\
\text { Ingested DA }\end{array}$} \\
\hline & \multicolumn{2}{|c|}{$\left(\right.$ Cells $\left.\mathbf{m L}^{-1}\right)$} & \multicolumn{2}{|c|}{$\left(\right.$ pg DA Cell $\left.{ }^{-1}\right)$} & & & & \\
\hline & Initial & End & Initial & End & & & & \\
\hline \multicolumn{9}{|l|}{ Controls } \\
\hline P. seriata & $3964 \pm 40$ & $5048 \pm 102$ & $0.1 \pm 0.0$ & $0.1 \pm 0.0$ & & & & \\
\hline P. obtusa & $5061 \pm 32$ & $8907 \pm 683$ & $<\mathrm{LOD}$ & $<\mathrm{LOD}$ & & & & \\
\hline P. seriata + P. obtusa & $7144 \pm 103$ & $8617 \pm 122$ & $0.1 \pm 0.0$ & $0.2 \pm 0.0$ & & & & \\
\hline \multicolumn{9}{|l|}{ Treatments } \\
\hline P. seriata + copepodites & $3951 \pm 52$ & $1901 \pm 187$ & $0.1 \pm 0.0$ & $2.6 \pm 0.6 *, * *$ & $530 \pm 21$ & $70 \pm 18$ & $410 \pm 112$ & $13 \pm 4$ \\
\hline P. obtus $a+$ copepodites & $5951 \pm 285$ & $4988 \pm 570$ & $<\mathrm{LOD}$ & $0.2 \pm 0.1 *, * *$ & $137 \pm 37$ & $8 \pm 2$ & $48 \pm 10$ & $6 \pm 2$ \\
\hline $\begin{array}{l}P . \text { seriata }+P . \text { obtusa }+ \\
\text { copepodites }\end{array}$ & $7033 \pm 97$ & $4262 \pm 249$ & $0.1 \pm 0.0$ & $3.7 \pm 0.6^{*, * *}$ & $275 \pm 70$ & $42 \pm 8$ & $246 \pm 51$ & $16 \pm 4$ \\
\hline
\end{tabular}

\subsubsection{Grazing and Fecal Pellet Production}

The copepodites produced fecal pellets on all diets (Figure 1a) proving that the copepodites grazed on the toxic algae. Of the 146 copepodites used in the experiment, 138 were alive and vital at the end of the experiment, and no dead copepodites were found in the samples at the end. Two of the missing copepodites were discovered in the cell enumeration samples, six were missing. The mean clearance rate for the $39 \mathrm{~h}$ was the same $\left(2.8 \pm 0.7-3.3 \pm 0.6 \mathrm{~mL} \mathrm{cop}^{-1} \mathrm{~h}^{-1}\right)$ for all three treatments (one-way ANOVA, $F_{2,9}=0.3, P=0.8$ ) (Figure 2a); and there was not signifcant difference among ingestion rates, either when grazing on $P$. seriata, P. obtusa or a mixture of both species (one-way ANOVA, $\left.F_{2,9}=0.3, P=0.7\right)$. We found no significant changes in weight-specific ingestion rates between the light and the dark periods in any of the diets (RM ANOVA, $P>0.05$ ) (Supplementary Figure S1), and the average ingestion rate during the $39 \mathrm{~h}\left(0.56 \% \pm 0.1 \%-0.77 \% \pm 0.2 \% \mathrm{~h}^{-1}\right)$ did not differ among the diets (one-way ANOVA, $F_{2,9}=0.3, P=0.8$ ) (Figure 2B). 

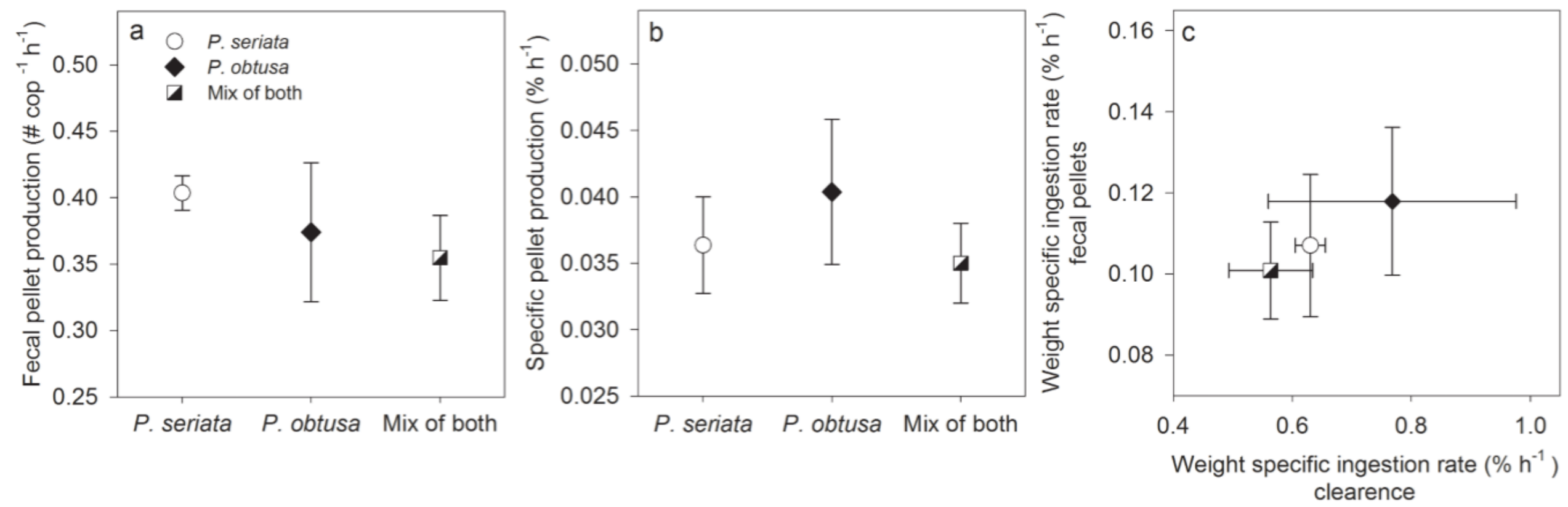

Figure 1. Fecal pellet production and weight-specific ingestion rate in the $39 \mathrm{~h}$ grazing experiment. (a) Fecal pellet production $\left(\right.$ cop $\left.^{-1} \mathrm{~h}^{-1}\right)$; and (b) specific fecal pellet production (SPP) $\left(\% \mathrm{~h}^{-1}\right)$ when grazing on P. seriata, P. obtusa or a mixture of both species. No significant differences were found among treatments; (c) Weight-specific ingestion rate $\left(\% \mathrm{~h}^{-1}\right)$, calculated from fecal pellet production and from clearance were plotted against each other for the three diets. The weight-specific ingestion rate was statistically higher when calculated from clearance, than calculated from fecal pellet egestion. 

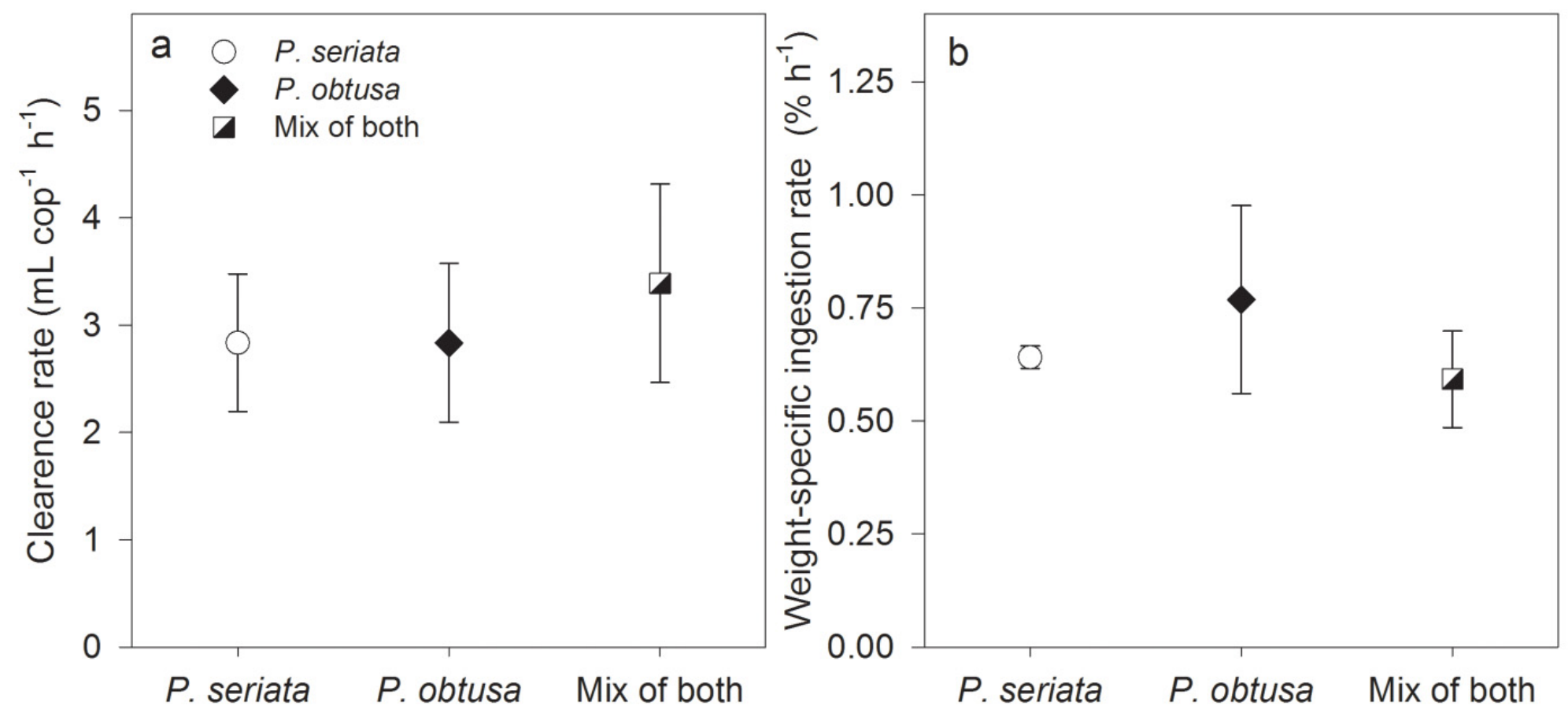

Figure 2. Grazing in the $39 \mathrm{~h}$ experiment. (a) Mean clearance rate $\left(\mathrm{mL}^{-1} \mathrm{cop}^{-1} \mathrm{~h}^{-1}\right.$, mean $\pm \mathrm{SD}$ ) for grazing on $P$. seriata, $P$. obtusa or a mixture of both species; (b) Weight-specific ingestion rates $\left(\% \mathrm{~h}^{-1}\right.$, mean $\left.\pm \mathrm{SD}\right)$ for grazing on $P$. seriata, $P$. obtusa or a mixture of both species. No statistical differences were found among treatments. 
Fecal pellet production was highest when grazing on $P$. seriata, and specific fecal pellet production (SPP) was highest when grazing on P. obtusa (Figure 1b). However, no significant differences were found in number of fecal pellets produced (one-way ANOVA, $F_{2,9}=1.3, P=0.4$ ) nor in SPP among the diets (one-way ANOVA, $F_{2,9}=1.0, P=0.4$ ). Comparison of the weight-specific ingestion rates, based on clearance of carbon or based on fecal pellet egestion, showed a higher ingestion rate when based on clearance, than egestion when grazing on all three diets ( $t$-tests; $P$. seriata and mix of both species $P<0.001$, and $P$. obtusa Mann-Whitney Rank Sum Test, $P=0.03$ ). For both calculation methods, a comparison of the ingestion rate among the diets showed the highest ingestion rate on P. obtusa, and the lowest on the mixed diet (Figure 1c).

\subsubsection{Growth Conditions}

The initial cell density in each of the diet treatments was the same as in the controls ( $t$-test; for $P$. seriata $P=0.7 ;$. obtusa $P=0.1$ and in the treatment with mixed cultures: $P$. seriata $P=0.9$ and $P$. obtusa $P=0.1)$. Overall, no significant changes or trends in changes of concentrations of phosphate $\left(\mathrm{PO}_{4}{ }^{3-}\right)$, ammonium $\left(\mathrm{NH}_{4}{ }^{+}\right)$and nitrate $\left(\mathrm{NO}_{3}{ }^{-}\right)$were observed, although single samples differed either from start to end or between control and treatment (see details in Supplementary Table S1). Silicate $\left(\mathrm{Si}(\mathrm{OH})_{4}\right)$ concentrations decreased significantly in all the controls from start to end of the experiment, whereas in the treatments with copepodites there was no significant change. The $\mathrm{pH}$ levels were $8.1 \pm 0.1$ in the controls and the treatments at the start of the experiment and $8.1 \pm 0.03$ at the end of the experiment, and no overall significant changes were observed among the treatments containing copepodites and the controls (see details in Supplementary Table S1).

\subsection{Induction Experiments}

\subsubsection{Toxicity}

Domoic acid cell quota (toxicity) in P. seriata increased significantly in both copepodite density treatments, both in flask A with cells in direct contact with the grazers (Figure 3a), and in flask B with cells separated from the grazers (Figure 3b) (RM ANOVA, P-values $<0.05$, except for flask A day 2 to 5, where non-induced cells were added on day 3 ). Overall, the DA cell quota gradually increased in flask A from day 0 to day 8, whereas the response was delayed in flask B (Figure 3). In the control, DA cell quota did not change during the experiment, it was consistently in the range $0.3 \pm 0.1$ to $0.4 \pm 0.0 \mathrm{pg}$ DA cell ${ }^{-1}$ (RM ANOVA, $F_{2,6}=38.8, P=0.08$ ). From day 0 to 2 , toxicity of $P$. seriata increased significantly only in flask A ( $t$-tests, with 12 copepodites $P<0.001$ and with $20 P=0.003$ ). On day 2 , the DA cell quota was significantly higher in flask A than in B $(t$-tests: $P=0.002$ and $P<0.001$ for 12 and 20 copepodites, respectively). After day 2, toxin content was the same in flask $\mathrm{A}$ and $\mathrm{B}$ in both concentrations of copepodites ( $t$-tests, $P>0.05)$. The highest level of DA was $13.3 \pm 4.9 \mathrm{pg} \mathrm{DA} \mathrm{cell}^{-1}$ in flask A with 12 copepodites on day 8 (Figure 3 and Supplementary Table S2). In the experiment where cells of $P$. seriata were grown in filtrate water, where the copepodites had previously been grazing on Thalassiosira sp., the increase in DA cell quota was from $0.2 \pm 0.0$ to $2.4 \pm 0.2 \mathrm{pg} \mathrm{DA} \mathrm{cell}^{-1}$ in $39 \mathrm{~h}$ (paired $t$-test, $P=0.002$ ) (Figure $3 \mathrm{c}$ ). 


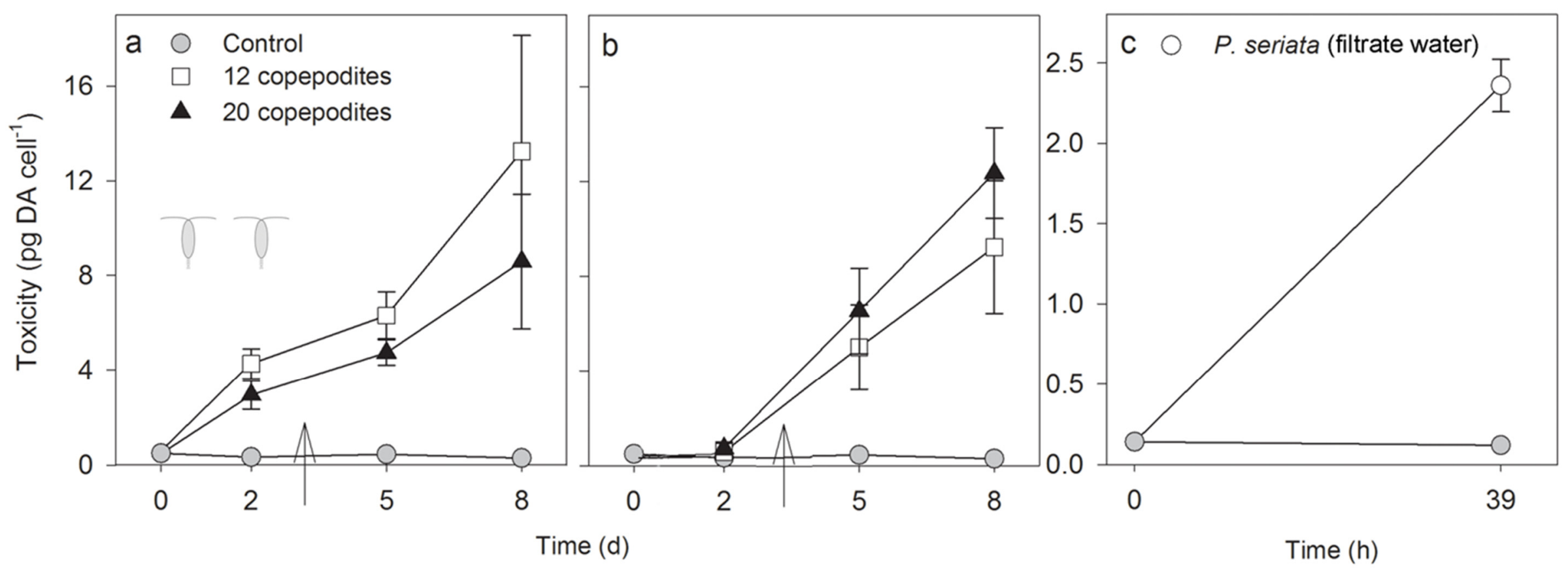

Figure 3. Domoic acid cell quota (pg DA cell ${ }^{-1}$, mean $\pm \mathrm{SD}$ ) of $P$. seriata when grazed by two different concentrations of copepodites and in the control. (a) Flask A with copepodites and P. seriata $(n=4)$; (b) Flask B with only P. seriata cells separated from the copepodites by a $2 \mu \mathrm{m}$ membrane $(n=4)$. The control contains $P$. seriata cells $(n=3)$. The arrows indicate the time when cells were added to ensure the copepodites had enough food; (c) Toxicity of $P$. seriata (pg DA cell ${ }^{-1}$, mean $\pm \mathrm{SD}$ ) when grown in the filtrate water where copepodites had been grazing on another diatom species (Thalassiosira sp.) Note the different scales in (c). 


\subsubsection{Growth Rate, Cell Density and Growth Condition}

The initial cell concentrations were the same in all treatments and in the controls at the start of the experiment (one-way ANOVA, $F_{2,11}=3.7, P=0.05$ ). Mean growth rates (eight days) in all incubators containing only $P$. seriata cells, i.e., flasks B and controls, were the same (Kruskal-Wallis test, $P=0.7$ ), indicating similar growth conditions (Figure 4). The growth rates were slightly lower during the first two days, $0.1 \pm 0.9 \mathrm{~d}^{-1}$ and stabilized thereafter around $0.3 \pm 0.1 \mathrm{day}^{-1}$. The cell density was significantly lower in flask A than in flask B on day 2 in both treatments (12 and 20 copepodites) (Figure 5b) ( $t$-test, $P<0.001$ and Mann-Whitney Rank Sum Test, $P=0.029$ ) illustrating that the copepodites grazed on the toxic cells. Despite the addition of cells in flask A on day 3, the cell numbers were significantly lower in flask A than in flask B on day 8 in both treatments (Figure 5) ( $t$-test, $P=0.018$, and Mann-Whitney Rank Sum Test, $P=0.029$ ).

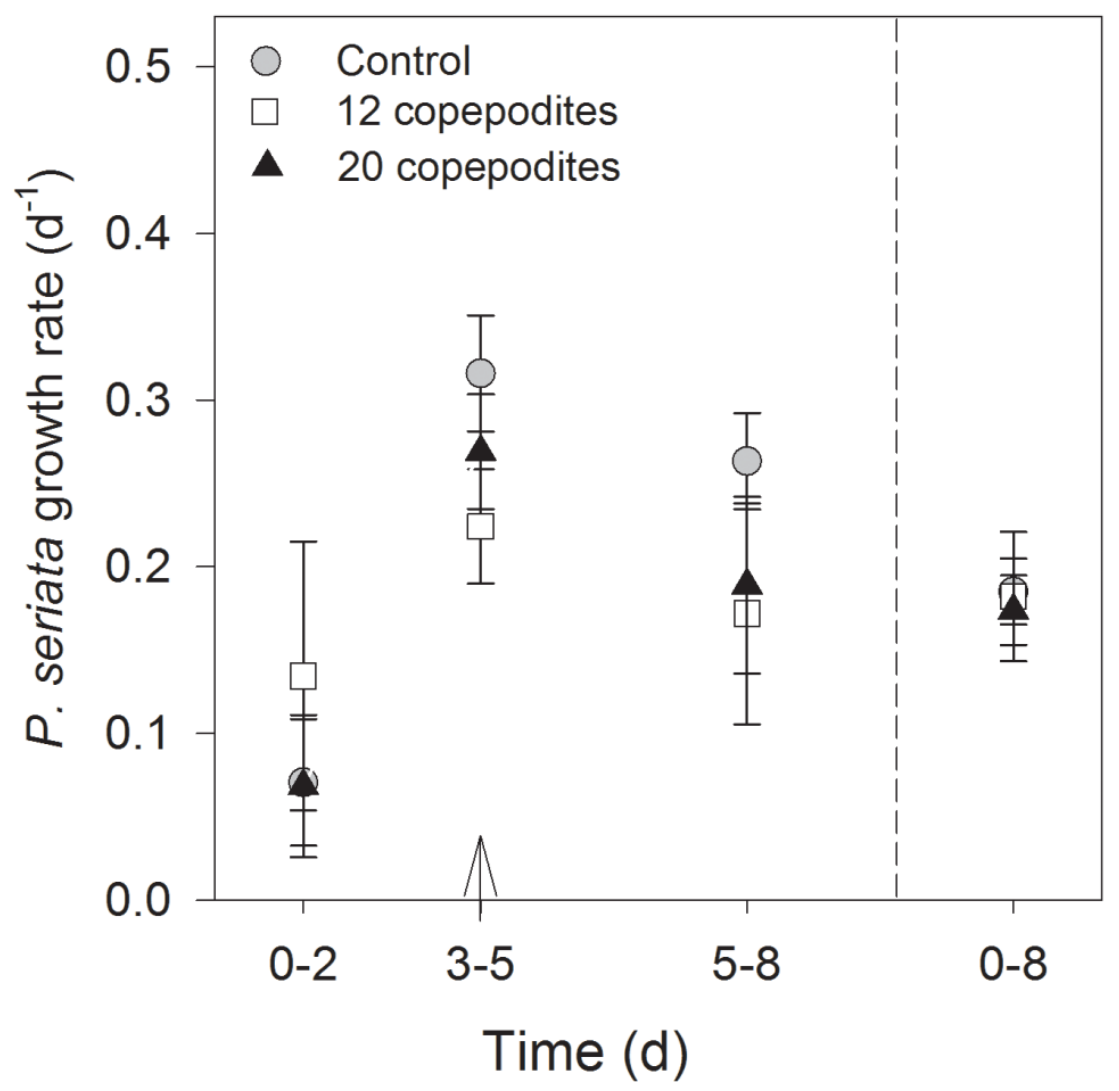

Figure 4. Growth rate $\left(\right.$ day $\left.^{-1}\right)$ in flask B containing only $P$. seriata cells, and the controls. On day 3 , the flasks were diluted with $1 / 10 \mathrm{~L}$ medium (arrow) to compensate for adding cells to the other site of the chamber where the copepodites had reduced the cell concentration drastically. No statistical differences were found among treatments. 

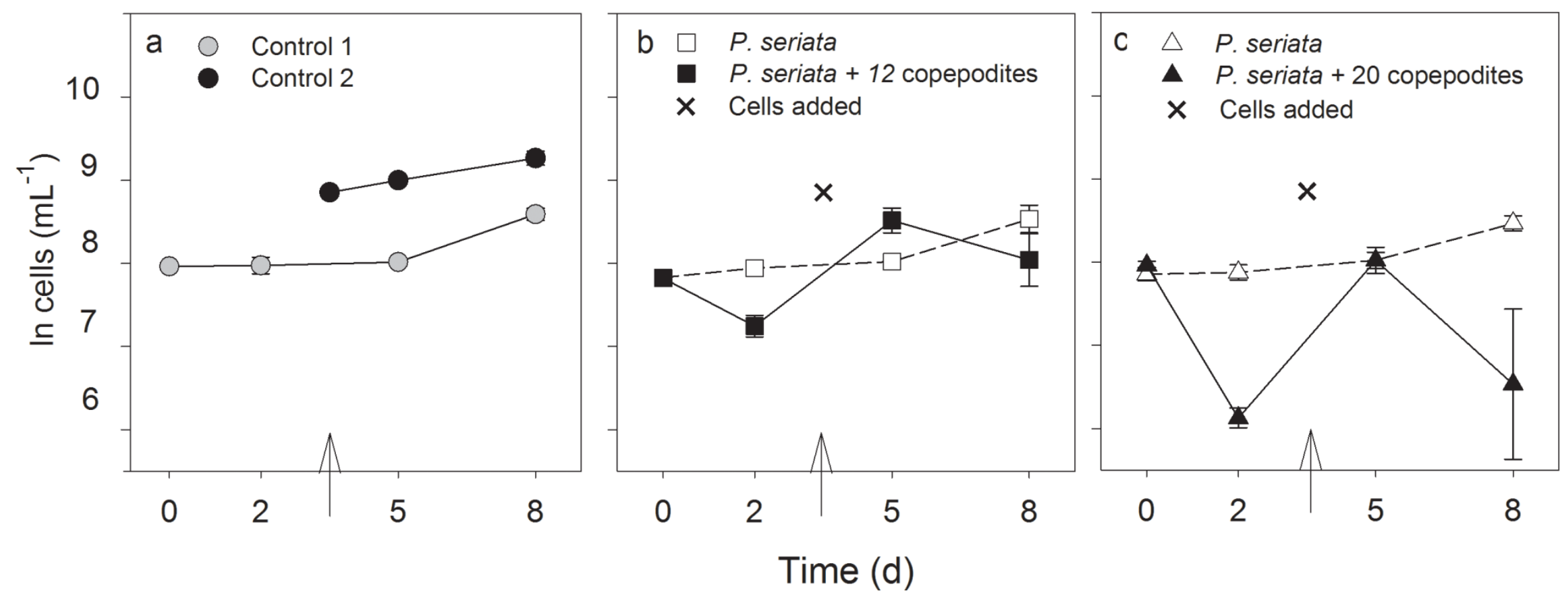

Figure 5. (a) Cell concentrations ( $\ln$ cells $\mathrm{mL}^{-1}$, mean $\pm \mathrm{SD}$ ) in the induction experiment. (a) The two controls (both $n=3$ ); (b) Cell concentrations in flask A with 12 copepodites and flask B with only P. seriata cells separated from flask A by a $2 \mu \mathrm{m}$ membrane $(n=4)$. (c) Cell concentrations in flask A with 20 copepodites and flask B with only cells separated from flask A by a $2 \mu \mathrm{m}$ membrane $(n=4)$. The cross and arrows indicate the time and the amount for $P$. seriata cells or $1 / 10 \mathrm{~L}$ medium addition. 
Overall, the nutrient measurements showed a significantly larger decrease in silicate concentration in the control than in the treatments, relatively stable concentrations of phosphate and ammonium throughout the experiment (although single samples differed either from start to end or between control and treatment (see details in Table 2)), and a significantly higher end concentration of nitrate in the treatments than in the control (Table 2). Because only two measurements were available for the initial concentration of nitrate, it was not included in the statistical tests. The initial $\mathrm{NO}_{3}: \mathrm{Si}(\mathrm{OH})_{4}: \mathrm{PO}_{4}{ }^{3-}$ ratios were $\sim 23: 1: 1$. The $\mathrm{pH}$ levels were 8.1 at the start of the experiment and varied between 8.1 and 8.2 at the end of the experiment (Table 2), with no statistical difference between the treatments and the controls.

Table 2. Induction experiments. Nutrient concentrations and $\mathrm{pH}$ levels at the start and the end of the induction experiments. $n$ is the number of copepoditesr. Values are given as mean \pm SD. Results are given as $*=$ significant difference between start and end and $* *$ = significant difference between the control and the treatment.

\begin{tabular}{|c|c|c|c|c|c|c|}
\hline $\begin{array}{c}\text { Time } \\
\text { (day)/(h) }\end{array}$ & Treatment & $\mathrm{Si}(\mathrm{OH})_{4}\left(\mu \mathrm{mol} \mathrm{L} \mathrm{L}^{-1}\right)$ & $\mathrm{PO}_{4}{ }^{3-}\left(\mu \mathrm{mol} \mathrm{L} \mathrm{L}^{-1}\right)$ & $\mathrm{NH}_{4}^{+}\left(\mu \mathrm{mol} \mathrm{L}^{-1}\right)$ & $\mathrm{NO}_{3}{ }^{-}\left(\mu \mathrm{mol} \mathrm{L} \mathrm{L}^{-1}\right)$ & pH \\
\hline 0 & Initial & $5.7 \pm 0.6$ & $5.6 \pm 0.6$ & $38.3 \pm 1.6$ & $131.6 \pm 5.6$ & 8.10 \\
\hline 8 & Control & $0.0 *$ & $3.5 \pm 0.3 *$ & $25.6 \pm 1.0 *$ & $99.3 \pm 6.3$ & $8.12 \pm 0.02$ \\
\hline 8 & Flask A, $n=12$ & $1.3 \pm 1.0 *$ & $6.6 \pm 1.2 * *$ & $28.8 \pm 2.3$ & $182.6 \pm 20.7 * *$ & $8.16 \pm 0.02$ \\
\hline 8 & Flask A, $n=20$ & $3.6 \pm 0.7 *, * *$ & $7.1 \pm 0.5 *, * *$ & $33.9 \pm 0.7 * *$ & $191.2 \pm 4.2 * *$ & $8.12 \pm 0.02$ \\
\hline 8 & Flask $\mathrm{B}, n=12$ & $0.4 \pm 0.7 *$ & $5.5 \pm 1.1$ & $25.9 \pm 1.4$ & $164.2 \pm 17.7 * *$ & $8.18 \pm 0.00$ \\
\hline 8 & Flask $\mathrm{B}, n=20$ & $0.4 \pm 0.3 *$ & $5.1 \pm 0.1$ & $27.9 \pm 1.5$ & $161.4 \pm 10.5 * *$ & $8.11 \pm 0.01$ \\
\hline 0 & Initial & $6.7 \pm 0.6$ & $7.0 \pm 0.2$ & $38.8 \pm 1.7$ & $164.8 \pm 12.5$ & $8.06 \pm 0.00$ \\
\hline $39 \mathrm{~h}$ & Control & $3.6 \pm 0.3 *$ & $7.4 \pm 0.1 *$ & $39.9 \pm 1.0$ & $177.7 \pm 1.0$ & $8.09 \pm 0.01$ \\
\hline $39 \mathrm{~h}$ & End & $3.7 \pm 0.31 *$ & $8.0 \pm 0.4 *$ & $43.3 \pm 0.7 *, * *$ & $197.7 \pm 1.1 *, * *$ & $8.10 \pm 0.01$ \\
\hline
\end{tabular}

\subsubsection{Grazing and Retained Domoic Acid}

The average clearance rate was $0.7 \pm 0.1 \mathrm{~mL} \mathrm{cop}^{-1} \mathrm{~h}^{-1}$ in flask $\mathrm{A}$ with 12 copepodites and $1.1 \pm 0.2 \mathrm{~mL} \mathrm{cop}^{-1} \mathrm{~h}^{-1}$ with 20 copepodites. The average weight specific ingestion rate ( $0-8$ days) was the same in both treatments $\left(0.4 \% \pm 0.0 \% \mathrm{~h}^{-1}\right)$. The lowest ingestion rate was measured between days 0-2 and highest between days 3-5 after additional cells had been added (Figure 6). At the end of the experiment, 106 of the initial 128 copepodites were alive and vital. In the treatment with 12 copepodites, one was dead, and in the treatment with 20 copepodites, six copepodites were dead, the remaining copepodites were not found. After eight days grazing on P. seriata, the copepodites retained $250 \pm 77$ and $171 \pm 29 \mathrm{ng} \mathrm{DA}$ cop $^{-1}$, in the treatments with 12 and 20 copepodites, respectively, corresponding to $2.3 \pm 0.7$ and $1.6 \pm 0.3 \mathrm{ng} \mathrm{DA} \mu \mathrm{g} \mathrm{C} \mathrm{C}^{-1}$. The $P$. seriata cells produced on average $8.1 \pm 2.5 \times 10^{-4} \mathrm{ng}$ DA $\mu \mathrm{g} \mathrm{C} \mathrm{C}^{-1}$. 


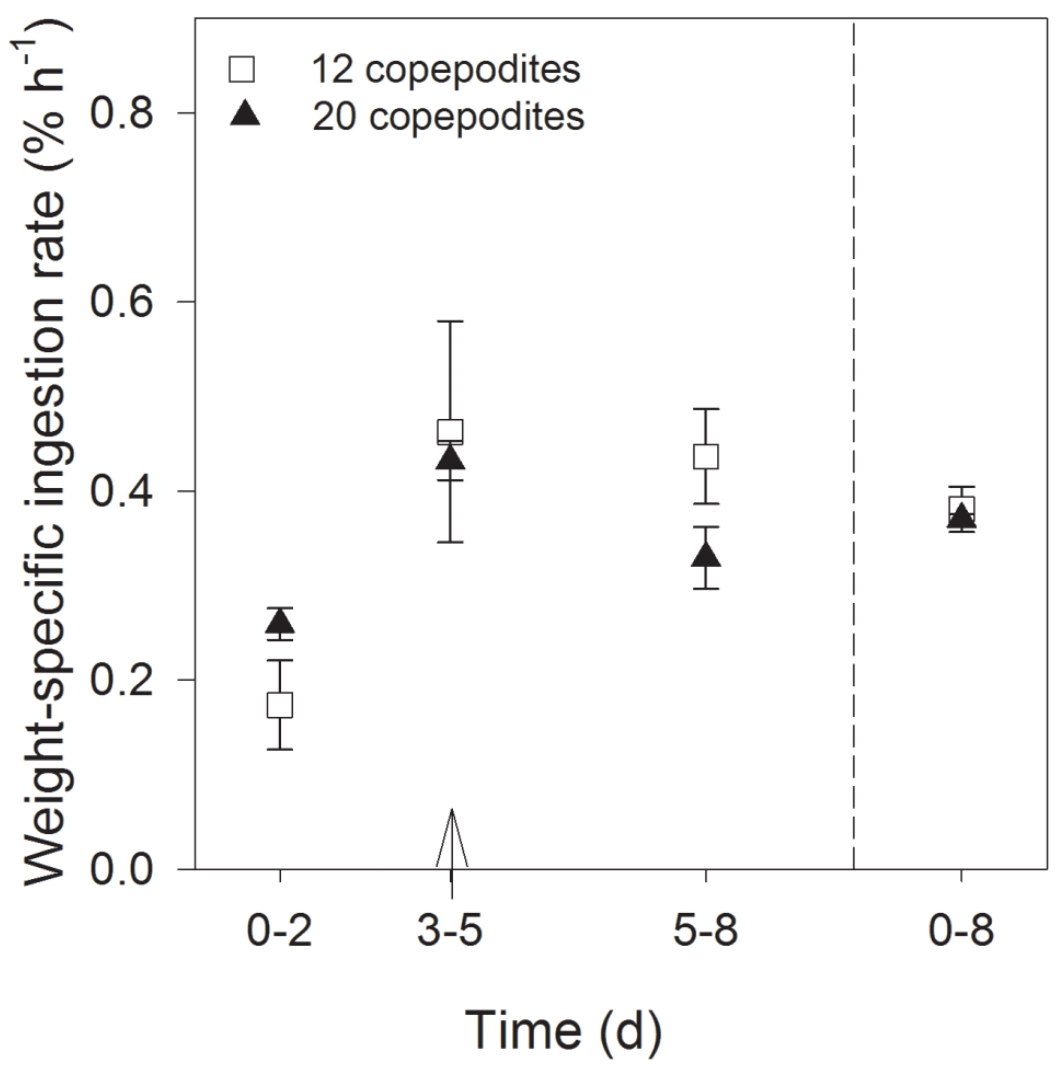

Figure 6. Weight specific ingestion rate of the two concentrations of grazers $\left(\% \mathrm{~h}^{-1}\right.$, mean $\pm \mathrm{SD}$ ). The arrows indicate the time when cells were added to ensure the copepodites had enough food.

\section{Discussion and Conclusions}

\subsection{Calanus Copepodites Grazing on Pseudo-nitzschia}

\subsubsection{Grazing}

In this study we show for the first time that Calanus copepodites stages $\mathrm{C} 3$ and $\mathrm{C} 4$ graze on toxic Pseudo-nitzschia and retain the toxin, suggesting that copepodites pose a risk as vectors of DA in arctic marine food. The results suggest that DA did not deter grazing, which may seem as a paradox because the algae induce toxin production in the presence of grazing copepodites. But DA may affect other physical capabilities of the grazer, e.g., the competency to escape predators. This has been seen in the copepods Oithona similis and C. helgolandicus, which were negatively affected (disoriented or dead) after feeding on a toxic strain of Alexandrium tamarense [32]. Other potential effects of DA could be a reduction in fecundity and hatching rate of eggs, as has previously been demonstrated for the rotifer Brachionus plicatilis [33]. The ingestion and clearance rates did not differ significantly among the treatments or within the treatments, i.e., between the light and dark periods, or on average over the $39 \mathrm{~h}$. The grazing rates were the same in the two experiments and were in the range found in the other studies on C. finmarchicus copepodites [34,35]. Our results are in agreement with the results of the majority of previous grazing studies on adult copepods, which have not shown DA to deter grazing by copepods, e.g., no selectivity was observed by [9] for the copepod Acartia clausi against the 
toxic $P$. multiseries compared to the non-toxic $P$. delicatissima. The same was seen for $C$. finmarchicus grazing on toxic $P$. multiseries and non-toxic $P$. pungens [15]. The results partly differ from the only study from the same location, where adult females of $C$. finmarchicus and $C$. hyperboreus were temporally affected when fed with toxic $P$. seriata [18], similar to a temporal grazing effect seen on krill [24]. Deterred grazing and/or mortality of copepods have been observed in other toxigenic algal groups, e.g., reduced grazing rates of $C$. pacificus were detected when grazing on toxic dinoflagellates [36,37]. Acartia tonsa ingested lower proportion of toxic Alexandrium minutum when offered a choice between A. minutum and non-toxic alternative prey Prorocentrum micans [24], and grazer mortality ranged from $36 \%$ to $47 \%$ for Centropages typicus and Acartia clausi, respectively, grazing on toxic A. minutum [38]. In the present study, both Pseudo-nitzschia species were, to our surprise, found to be toxic, and the copepodites fed continuously on the toxic $P$. seriata as well as on the less toxic P. obtusa. Hence, due to the lack of a non-toxic control, we cannot conclude that DA will not have any negative effects on the copepodites, since, e.g., ingestion rates might be higher on a non-toxic species than on the toxic species.

Selectivity for size (grazing differently on P. seriata, which is larger than P. obtusa) was not observed. This was expected as the copepodites were in the size range of $C$. pacificus and $C$. finmarchicus, and both $P$. seriata and P. obtusa are within the size range of prey of these species $[18,39]$. When culturing clonal strains of pennate diatoms, like Pseudo-nitzschia, they inevitably become shorter with time due to restrictions by the silica encasing during cell division - the MacDonald-Pfitzer rule [40]. The large cell size is regained during sexual reproduction. The cell length of the strains of $P$. seriata and $P$. obtusa were therefore small compared to observations of the species in the field. But since the Pseudo-nitzschia cells appeared in stepped colonies, which the copepodites apparently did not have difficulties handling, we do not expect that a larger cell size in the field will pose any differences in grazing. The copepodites were similar to the size of an adult $C$. finmarchicus, which has been reported to feed effectively on cells with considerable larger volumes than the cells of the present study [41], it can therefore be expected that the feeding response we see is representative for the feeding on natural populations.

We saw few (six out of 128) dead copepodites in the eight-day induction experiment, and this could to a minor degree be related to a hypothesis of DA not acting as grazing deterrent but as a toxin. As we did not find any effect on grazing as an indication of the copepodites not being well, we do not consider it likely that the six dead copepodites had died because of the DA. Dissolved DA (dDA) has previously been found not to affect the grazing rate but having lethal effects on the copepod Tigriopus californicus [42], and dDA has been found to increase mortality of krill [43]. dDA was not measured in the present study, because the same strain had previously been found to leak DA only in very low amounts in exponential growth phase [18], and dDA was thus not considered relevant. Because most copepodites were alive after grazing on monocultures of toxic algae, we assume that neither dDA nor accumulated DA caused copepodite mortality.

The study organisms used here, Pseudo-nitzschia and Calanus, originate from the same locality, meaning that the Calanus population may have a long history of exposure to DA. Local adaptation of copepods to toxins has been studied in Acartia spp. grazing on toxic dinoflagellates and has shown that populations with a long history of exposure to toxins show better performance (ingestion rate and egg production) when exposed to toxic algae, in comparison to naïve populations with no previous 
experience of the toxins [44-48]. If zooplankton populations, e.g., Calanus copepodites, are adapted to algal toxins, this may hypothetically, result in a reduced algal cell concentration or shorter duration of a toxic algal bloom due to grazing, compared to presence of naïve zooplankton (i.e., less reduction in grazing). On the other hand, zooplankton populations adapted to algal toxins may accumulate greater quantities of toxins in their bodies, and therefore pose a larger risk for accumulation of toxins in the food web and further increased risk of ASP in humans. Something similar has been observed in the clam Mya arenaria where a variation in resistance/sensitivity to paralytic shellfish toxins produced by Alexandrium tamarense was found. Clams from areas exposed to the toxins were more resistant to the toxins and accumulated the toxins at higher rates than clams from non-exposed areas, indicating an adaptation to the toxin [49].

The production of fecal pellets confirms that the copepodites were grazing on the algae. The pellet production in this study was 0.3 to 0.4 pellets copepodite ${ }^{-1} \mathrm{~h}^{-1}$, which is lower than found for C. finmarchicus copepodites stages C4 and C5 [35]. This can partly be explained by the accumulation of lipids, which may be higher in stages $\mathrm{C} 3$ and $\mathrm{C} 4$ than in $\mathrm{C5}$, as suggested in [50], thus illustrating that the younger stages of copepodites are exploiting the ingested food to a higher degree that the older stages. The lipids are essential for the overwintering mechanism and early provision for fueling maturation, gonad development and reproduction in the spring [51,52]. The high degree of food exploitation may further explain the lower weight-specific ingestion rates found when calculations were based on fecal pellets egestion than on clearance of carbon, as the calculations are based on assumptions made on adult copepods [53-56] (Figure 2c).

\subsubsection{Copepodites as Vectors in the Arctic Food Web}

This present study is the first conducted on copepodites as potential vectors for DA in the food chain and the results clearly show that the copepodites retain DA. The amount of retained DA, in relation to body weight, ranged from $48 \mu \mathrm{g}$ DA g DW cop $^{-1}$ when grazing on P. obtusa, to $410 \mu \mathrm{g}$ DA g DW cop ${ }^{-1}$ when grazing on $P$. seriata, for $39 \mathrm{~h}$. This is in range with the amounts in Tammilehto et al. [18], where the adult Calanus grazed for $12 \mathrm{~h}$ on $P$. seriata and the DA retained ranged from $68 \mu \mathrm{g}$ DA g DW cop ${ }^{-1}$ in C. glacialis to $290 \mu \mathrm{g}$ DA g DW cop $^{-1}$ in C. finmarchicus. The body weight of the copepodites was similar to the size of an adult $C$. finmarchicus $\left(\sim 0.11 \mathrm{mg} \mathrm{C}^{-1}\right)$. The amount of DA retained per copepod, $68 \mathrm{ng}$ DA $\operatorname{cop}^{-1}$ when grazing on P. seriata for $39 \mathrm{~h}$, is in the range of what has previously been found for adult females; i.e., C. finmarchicus was found to accumulate $17 \pm 5 \mathrm{ng}$ DA $\operatorname{cop}^{-1}$ when fed mixed diet of toxic P. multiseries and non-toxic P. pungens, and $42 \pm 4 \mathrm{ng} \mathrm{DA} \operatorname{cop}^{-1}$ on a diet of $P$. multiseries for $12 \mathrm{~h}$ [15]. The results are also similar to the values found in [18], i.e., $55 \pm 10 \mathrm{ng} \mathrm{DA} \operatorname{cop}^{-1}$ for C. finmarchicus grazing on P. seriata for $12 \mathrm{~h}$. The percentage of ingested DA retained in the copepodites ranged from $6 \% \pm 2 \%$ when grazing in P. obtusa to $16 \% \pm 4 \%$ when grazing on a mixture of both species. This is slightly lower than for adult Calanus spp. where values ranged from $37 \% \pm 32 \%$ to $48 \% \pm 20 \%$ in C. hyperboreus and C. finmarchicus [18] but in the range of the findings in [15], $12 \% \pm 5 \%$ to $34 \% \pm 19 \%$. These relatively high levels of DA retained in copepodites clearly illustrate a potential risk for accumulation of DA in the arctic food web during a toxic bloom of Pseudo-nitzschia. The amount of DA retained in Calanus copepodites was higher in DA per $\mu \mathrm{g}$ carbon than in the Pseudo-nitzschia cells. Furthermore, 
the levels found in the copepodites were higher than amounts that have been found in krill $\left(<45 \mu \mathrm{g}\right.$ g DW krill $\left.{ }^{-1}\right)$ [43].

\subsection{Induction of Domoic Acid Production in Pseudo-nitzschia by Grazing Copepodites}

In this study, we saw that DA production was enhanced by $3300 \%$, and reached $\sim 13$ pg DA cell ${ }^{-1}$ on day 8 , similar to levels was reported by Tammilehto et al. [20] who found that toxicity of $P$. seriata (the same strain as used in this experiment) increased significantly in the presence of grazing adult females of $C$. finmarchicus and C. hyperboreus. In the present study, DA cell quota was the same in flask B (where the cells were separated from the copepodites) as in flask A (where the cells were in direct contact with the grazers) after day 2, but with a delayed increase in DA cell quota during the first two days, whereas in [20] P. seriata was markedly more toxic in flask A than in flask B. This may be explained by the higher densities of grazers used in the present study compared to [20], or that the cues produced by the copepodites may consist of smaller molecules that more easily diffuse over the membrane. Further we can confirm that the cues were not produced by $P$. seriata cells, as the induction was also observed when $P$. seriata cells grew in filtered seawater, where copepodites had been grazing only on Thalassiosira sp. The origin of the cues must therefore be the copepodites. Recently, eight cueing compounds, copepodamides, were isolated and identified from Centropages typicus, Pseudocalanus sp. and Calanus finmarchicus, and found to be responsible for toxin induction in Alexandrium minutum [57]. The copepodamides differed among copepodites, and toxin production in A. minutum was shown to be compound specific. Species-specific elevation of toxin production has previously been reported for dinoflagellates $[32,38]$ and for our strain of $P$. seriata.

Triggers for induced DA production have previously been found to be environmental factors, e.g., nutrient levels, reviewed in [11], and $\mathrm{pH}[23,58]$. Pseudo-nitzschia has been found to increase toxin production when stressed by depletion of silicate or phosphate [21], and when ammonium or nitrate levels are replete [22,59]. The growth medium in this study was 1/10 of L-medium with additional ammonium spiked into filtered seawater from the locality (see in detail in Material and Methods) in order to supply the cells with enough nutrients for growth and DA production and to avoid artifacts from extreme nutrient conditions. The measured initial nutrient levels were, however, low for both silicate and phosphate, due to the low nutrient levels in the seawater used. Levels of silicate decreased significantly in treatments and in the controls, but the increase in the toxicity of $P$. seriata was only seen in the treatments with copepodites (Table 2 and Supplementary Table S1) and not in the controls, excluding silicate depletion as trigger for DA production. At the end of the experiment, silicate levels were below $1 \mu \mathrm{M}$ in the control, which is the level previously considered as depleting, and where Pseudo-nitzschia spp. have previously been reported to induce DA production [21], however, in this study, depletion of silicate did not enhance DA production. Silicate was significantly higher in the treatments than in the controls at the end of the experiment, but to our knowledge, silicate depletion has never been shown to inhibit DA production in Pseudo-nitzschia. Phosphate concentrations decreased in the control but remained the same in the treatments, except in flask A with 20 copepodites, where phosphate increased significantly. In addition, phosphate was never below the depleting $1 \mu \mathrm{M}$ [21], and we can therefore exclude phosphate depletion as DA-inducing factor. The results show higher levels of silicate, phosphate and nitrate in the treatments with copepodites compared to the controls, 
and our assumption is that they partly derive from the intracellular content of inorganic nutrients released into the medium when the grazers crush the silicate frustules during grazing. Copepods may leak ammonium and high levels $(>200 \mu \mathrm{M})$ can lead to increased cellular DA quota in Pseudo-nitzschia [22]. Ammonium concentrations were the same in the control and the treatment, except for higher levels in one treatment (flask B, 20 copepodites) (Table 2), and the levels of ammonium were not in the range shown to cause increased DA-production [22]. Therefore, levels of ammonium cannot explain the induced DA production. High nitrate levels may also trigger DA production [22,59]. Nitrate concentrations were significantly higher in the treatments than in the control at the end of the experiment in the induction experiments. The source of the nitrate most likely originates from the addition of cells to the A-flasks on day 3. The input of cells may have resulted in addition of nutrients at higher levels than the 1/10 medium added to the controls, as the addition was based on a mixture of 1/10 medium of cells from a full medium culture. Another possibility is, as mentioned above, the nitrate might originate from the Pseudo-nitzschia cells when crushed during grazing. Further, the nitrate might originate from the copepodites via nitrification occurring on the carapace of the animals, a phenomenon that is not uncommon among aquatic invertebrates [60]. The ammonium excretions of the copepodites would be a source of ammonium for ammonia-oxidizing bacteria [61]. To support this hypothesis an increase in nitrogen has been detected in incubation of starving C. hyperboreus from the same locality (Peter Stief, personal communication) [62]. It should be pointed out that the levels of nitrate at the start of both the $39 \mathrm{~h}$ induction experiment and the grazing experiment were in range with the end concentration of the eight-day induction experiment, and as the latter experiment controls and treatment end concentrations did not differ in spite of different DA levels, we thus exclude nitrate as a trigger.

Studies conducted on natural population have demonstrated that low silicate $\mathrm{Si}(\mathrm{OH})_{4}: \mathrm{PO}_{4}$ and $\mathrm{Si}(\mathrm{OH})_{4}: \mathrm{NO}_{3}$ ratios correlated with high DA-production, suggesting silicate limitation causing toxin production [63]. However, at the same locality, [64] reported correlations between low ratios of $\mathrm{Si}(\mathrm{OH})_{4}: \mathrm{PO}_{4}{ }^{-3}$ and $\left(\mathrm{NO}_{3}{ }^{-}+\mathrm{NO}_{2}{ }^{2-}\right): \mathrm{PO}_{4}{ }^{3-}$ correlated with the enhancement in DA production, but low $\mathrm{Si}(\mathrm{OH})_{4}:\left(\mathrm{NO}_{3}{ }^{-}+\mathrm{NO}_{2}{ }^{2-}\right)$ ratios did not. These studies are partly in agreement with the results of laboratory results showing that silica stress increases toxin production in Pseudo-nitzschia. Other studies have, however, not detected any correlation with ambient concentrations of the nutrients and DA production [65,66]. Further, DA production in natural population of Pseudo-nitzschia has been measured when the levels of nutrient where replete [67]. In the present study, the nutrient levels of the local seawater were not available prior to the experiments and not within the Redfield ratio. In both the treatment and the control, the nutrient levels were closer to the ratio suggested to elicit DA production; nonetheless, DA was not induced in the controls. Our findings are therefore not in agreement with the previous in laboratory experiments, and the divergence between the field studies further clearly demonstrates that there is a lack of a strong relationship between the level of nutrient levels and DA production in the field. Studies exploring the interaction of factors inducing DA production are needed to improve our understanding of the factors inducing DA production in the field.

The cellular toxin levels in the present study were higher than previously seen in some laboratory experiments with P. seriata, where e.g., phosphate as the depleting factor resulted in a maximum of $2.9 \mathrm{pg}$ DA cell ${ }^{-1}$, but were comparable to levels under silicate depletion were the cells produced max $14.7 \mathrm{pg}$ DA cell ${ }^{-1}[22]$. The levels of DA induced during exponential growth phase are within the 
range seen in P. seriata in the field, e.g. a concentration of up to $21 \mathrm{pg}$ DA cell ${ }^{-1}$ was reported in [68] in Danish waters. Similar concentrations have been measured from Danish, Scottish and Canadian strains, which yielded DA concentrations of up to $33.6 \mathrm{pg} \mathrm{cell}{ }^{-1}, 14.7 \mathrm{pg} \mathrm{cell}^{-1}$ and $7 \mathrm{pg} \mathrm{cell}{ }^{-1}$, respectively [69,70]. The levels of DA are further in the range found in the field for other Pseudo-nitzschia species e.g., 0.1-78 pg cell ${ }^{-1}$ in P. australis [71], 7-75 cell $^{-1}$ in field samples comprising mainly $P$. australis [72] and $0-117$ pg DA cell $^{-1}$ in samples containing a mixture of Pseudo-nitzschia species [64].

$\mathrm{pH}$ levels in the present study ranged between 8.1 and 8.2 and no significant differences were found between the start and end of the experiment or among treatments and controls. Therefore, $\mathrm{pH}$ as well as nutrient concentrations can be excluded as a cause for the inducing increased DA-production in P. seriata and P. obtusa.

\subsection{Toxin Production in the Previously Non-Toxic P. obtusa}

Our initial intention was to use $P$. obtusa as a non-toxic control strain to explore the effect of toxic diet on the copepodites. P. obtusa has previously been tested negative for DA during different growth phases, as well as at $\mathrm{pH}$ levels from 8.0-9.1 [58,73]. Initial tests showed that P. obtusa did not produce DA at present detection levels, but surprisingly it was revealed to be toxigenic when induced by copepodites. Whether P. obtusa simply produced DA at levels below the detection limit and toxin production was enhanced by the induction, or whether the toxin production was completely shut down before the induction and the production was turned on by the induction, cannot be determined in the present study and needs further attention, as well as the possibility that other Pseudo-nitzschia species are toxin producing when exposed to grazers.

\subsection{Overall Conclusion}

Calanus copepodites stages C3 and C4 grazed on toxic Pseudo-nitzschia and retained high levels of the toxin, suggesting that the copepodites are able to tolerate DA and act as vectors of DA to higher trophic levels, thus posing a threat to the arctic marine food web and the humans exploiting it. The presence of grazing copepodites induced DA production in both Pseudo-nitzschia species, suggesting that production of DA by Pseudo-nitzschia may be a defense mechanism against grazing, however in this study no effect were found on the grazing rate. An induced response was also elicited when the copepodites had previously been grazing on another diatom species, illustrating that the cues do not originate from Pseudo-nitzschia cells. The results from both experiments show that the induced response in production of $\mathrm{DA}$ is not caused by changes in nutrient levels or $\mathrm{pH}$, but suggest that the water borne cues originate from the copepodites. Finally, the present study is the first report of P. obtusa being a toxin-producing Pseudo-nitzschia species, the 15th known DA producer of this genus.Copepods, including copepodites, constitute an imperative link, transferring energy from primary producers to higher trophic levels, in marine food webs and consequences of an increase of $3300 \%$ increase in DA production due to grazing of copepodites may be profound for the marine food web, with further consequences for human health and economy. 


\section{Materials and Methods}

\subsection{Study Organisms}

\subsubsection{Zooplankton}

Mesozooplankton was collected from Disko Bay $\left(69^{\circ} 14^{\prime} \mathrm{N}, 53^{\circ} 23^{\prime} \mathrm{W}\right)$, West Greenland, in June 2013, from the upper $100 \mathrm{~m}$ using a WP-2 net $(200 \mu \mathrm{m})$. Calanus in stages C3 and C4 were identified by the number of urosome somites and picked individually in petri dishes placed on ice blocks using stereo microscopes (Nikon SMZ-1B and Leica Wild M3b). The copepodites were kept in the dark at $4{ }^{\circ} \mathrm{C}$ for a maximum of 2 weeks in $0.22 \mu \mathrm{m}$ filtered seawater and fed with Thalassiosira sp. Prior to the experiments, the copepodites were starved for $24 \mathrm{~h}$. Carbon content of the copepodites (C) was calculated from a length/weight regression using the equation given for post bloom period; $\mathrm{C}=0.0044 \times \mathrm{PL}^{3.57}$, where PL is prosome length (Table 3 ). Dry weight was calculated assuming the carbon weight to dry mass ratio to be 0.60 [53].

Table 3. Size and carbon content of the study organisms. Cell length and width $(\mu \mathrm{m})$, cell volume $\left(\mu \mathrm{m}^{3}\right)$, and carbon content (pg C cell ${ }^{-1}$ ) for Pseudo-nitzschia obtusa and P. seriata. Length promosome $(\mathrm{mm})$ and carbon weight of the copepodites, $\mathrm{n}$ is the number of cells/individuals measured and values are given in mean \pm SD.

\begin{tabular}{|c|c|c|c|c|}
\hline Pseudo-nitzschia & Cell Length $(\mu \mathrm{m})$ & Cell Width $(\mu \mathrm{m})$ & Cell Volume $\left(\mu^{3}\right)^{3}$ & Carbon Content (pg C cell $\left.{ }^{-1}\right)$ \\
\hline $\begin{array}{c}\text { P. obtusa } \\
n=23\end{array}$ & $33.5 \pm 3.2$ & $4.2 \pm 0.5$ & $489 \pm 149$ & 57.3 \\
\hline $\begin{array}{c}P . \text { seriata } \\
n=23\end{array}$ & $49.0 \pm 3.4$ & $5.4 \pm 0.8$ & $1163 \pm 383$ & 137.1 \\
\hline Calanus & Prosome length $(\mathrm{mm})$ & & & $\begin{array}{l}\text { Carbon content per } \\
\text { individual }\left(\mathrm{mg} \mathrm{cop}^{-1}\right)\end{array}$ \\
\hline$n=21$ & $2.5 \pm 0.5$ & & & $0.11 \pm 0.1$ \\
\hline
\end{tabular}

For calculations, phytoplankton growth rate in the controls was calculated using an exponential model and changes in phytoplankton concentrations in the grazing were calculated after [39]. Ingestion rate was calculated as number of food items consumed by each grazer and weight-specific ingestion was estimated by multiplying number of Pseudo-nitzschia cells ingested by the cellular carbon content and dividing it by the average carbon body weight of copepodites. For the equations in detail see [18].

At the end of the experiment, fecal pellets were counted and the size estimated. The width of $>20$ fecal pellets per treatment and the length $>30$ fecal pellets per replicate were measured, and only pellets that were at least $3 \times$ longer than wide were included. Fecal pellet volume was calculated assuming a cylinder shape and the carbon content was estimated by applying a volume to a carbon conversion factor of $0.043 \mathrm{pg} \mathrm{C} \mathrm{m}^{-3}$ [54]. Specific fecal pellet production (SPP) was calculated according to [54] using number of fecal pellets, the average volume of fecal pellets and the pellet volume to carbon conversion factor. Weight-specific ingestion was calculated from fecal pellet production, i.e., egestion and assimilation efficiency following [55], and the assimilation efficiency was assumed to be 0.65 after [56]. All calculations were conducted following the equations as they appear in [18]. 


\subsubsection{Phytoplankton}

Strains of $P$. seriata (strain P5G3) and P. obtusa (strain L4B4) were isolated into clonal cultures from Disko Bay $\left(69^{\circ} 14^{\prime} \mathrm{N}, 5^{\circ} 23^{\prime} \mathrm{W}\right)$, in April 2010 and in April 2012, respectively, by isolating single cells or chains into micro well plates, and later inoculating the cultures into tissue culture flasks. Strain P5G3 was known to be a toxic strain of P. seriata, whereas P. obtusa was previously only known as a non-toxic species [73]. Strain P5G3 is the same strain as used in the previous experiments on Calanus and Pseudo-nitzschia in Disko Bay by Tammilehto et al. [18,20]. Prior to the experiments, both species were grown in batch cultures at $4{ }^{\circ} \mathrm{C}$ in L1-medium [74] under a light intensity of $85 \mu \mathrm{mol}$ photons $\mathrm{m}^{-2} \mathrm{~s}^{-1}$, at a 18:6 light:dark cycle using cool white fluorescent bulbs. Carbon cell

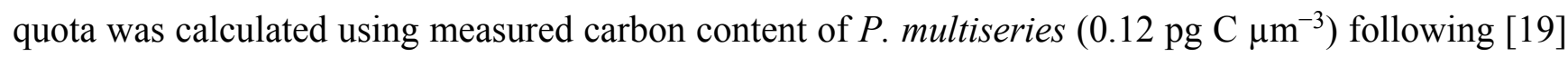
and relating this to the cell volume of $P$. seriata and P. obtusa. The cell volume of Pseudo-nitzschia spp. was calculated following [23]: volume $=\left(0.6 \times L \times W^{2}\right)+\left(0.4 \times 0.5 \times L \times W^{2}\right)$, where $L$ is the cell length and $W$ is the cell width (Table 3 ).

\subsection{Experiment Preparation, Nutrient and DA Analyses}

Actively swimming copepodites were sorted out in culture flasks filled with $0.22 \mu \mathrm{m}$ filtered seawater. Triplicate subsamples of copepodites were taken for DA analysis, where each replicate contained the same number of specimens as used in the experimental flasks. The copepodites were rinsed and filtered onto GF/F filters using gentle vacuum, and frozen at $-20{ }^{\circ} \mathrm{C}$ until toxin analysis.

Targeted initial diatom cell concentrations were prepared by diluting the cultures of $P$. seriata and $P$. obtusa with an appropriate volume of 1/10 L1-medium. The initial cell concentrations provided copepodites with saturating carbon supply $\left(>400 \mu \mathrm{g} \mathrm{C} \mathrm{L}^{-1}\right)$ [75]. To avoid artifacts from extreme nutrient concentrations, $1 / 10 \mathrm{~L} 1$ medium was used, based on $0.22 \mu \mathrm{m}$ filtered seawater with a salinity of 36. Additional ammonium chloride $\left(0.1 \mathrm{~mL}\right.$ of $\left.500 \mathrm{mM} \mathrm{NH}_{4} \mathrm{Cl} \mathrm{L}^{-1}\right)$ was added to the medium to avoid large differences in ammonium concentrations among treatments due to ammonium excreted by copepods [76]. Local seawater was used for the experiments, and we were unfortunately not able to measure nutrient levels before performing the experiment, and therefore the initial levels of silicate and phosphate were lower than anticipated. pH was measured using a WTW pH 3110 pH-meter with a SenTix 41 electrode (a sensor detection limit of 0.01; two point calibration) (WTW, Xylem), and triplicate subsamples of $50 \mathrm{~mL}$ for inorganic nutrient composition were taken. For measuring DA cell quota, triplicate subsamples of $200 \mathrm{~mL}$ P. seriata and P. obtusa were taken from the final culture for the experiments, and filtered onto GF/F filters. Nutrient samples and samples for DA analysis were stored at $-20{ }^{\circ} \mathrm{C}$ until analysis. The nutrients were analyzed at the Institute for Bioscience, Aarhus University in Denmark on a flow injection auto-analyzer, following [77]. DA analyses were conducted by liquid chromatography coupled with tandem mass spectrometry as described in details in [18]. Detection limit for DA was $1 \mathrm{ng}$ sample ${ }^{-1}$. All experiments were run at a temperature of $4{ }^{\circ} \mathrm{C}$, and a light intensity of $100 \mu \mathrm{mol}$ photons $\mathrm{m}^{-2} \mathrm{~s}^{-1}$ and 12:12 light:dark cycle using cool white fluorescent bulbs. The experimental flasks were mounted on a plankton wheel with speed $1.3 \mathrm{rpm}$. 


\subsection{Grazing Experiment}

The copepodites were fed with cultures of toxic $P$. seriata, non-toxic P. obtusa, and a mixture of both species. Each of the three grazing experimental treatments were carried out in $720 \mathrm{~mL}$ polystyrene flasks (Sarstedt) in four replicates with 12 copepodites per flask and run in parallel with controls in 3 replicates for $39 \mathrm{~h}$. The nominal initial cell concentration was 4000 cells $\mathrm{mL}^{-1}$ of $P$. seriata and 5000 cells $\mathrm{mL}^{-1}$ of $P$. obtusa, and 2000 cells $\mathrm{mL}^{-1}$ of $P$. seriata plus 5000 cells $\mathrm{mL}^{-1}$ of P. obtusa in the mixed culture for both treatments and controls (Table 3).

At the beginning and at the end of the experiment, samples for nutrients and DA as well as $\mathrm{pH}$ measurements were done as described in Section 4.4. Subsamples for enumerating cell concentrations were taken every $3 \mathrm{~h}$, and the volume removed was replaced with $0.22 \mu \mathrm{m}$ filtered seawater. At the end of the experiment $(39 \mathrm{~h})$, the copepodites and fecal pellets were collected as described in Section 4.4.

\subsection{Induction Experiment}

Induction experiment was carried out in specially designed incubators, made of two $720 \mathrm{~mL}$ polystyrene tissue culture flasks connected via two apertures $(4.5 \mathrm{~cm}$ in diameter) with a $2 \mu \mathrm{m}$ polycarbonate membrane, see details in Tammilehto et al. [20]. The transmission of food dye through the membrane was measured on a synergy scanner (Biotek), and the diffusion equilibrium was $\sim 30 \%$ after two days, matching the diffusion over a similar membrane in a set up made by Tang et al. [78]. The membrane allowed water exchange between the flasks but the plankton remained in their initial flasks, named A and B for the two sides. Cells of $P$. seriata and copepodites in concentrations of either 12 or 20 individuals were inoculated into flask A, and only P. seriata into flask B. The initial cell concentration of $P$. seriata was 3000 cells $\mathrm{mL}^{-1}$. The experiment was run in 4 replicates and a control in 3 replicates (using single flasks, $720 \mathrm{~mL}$ ) for eight days.

Subsamples for cell counts ( $2 \mathrm{~mL}$; fixed with $2 \%$ (final concentration) acidic Lugol's solution) and DA analyses $(200 \mathrm{~mL})$ were taken on days $0,2,5$ and 8 . The volume sampled was replaced with

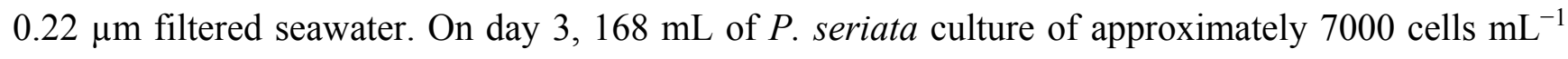
was added into flask A to supplement for a substantial amount of cells grazed by the copepodites and to ensure the copepodites a sufficient amount of cells for grazing. Similarly, $168 \mathrm{~mL}$ of 1/10 L1 medium was added to the controls and flask B. New controls in three replicates were subsequently established for measuring growth rate of the cells that had been added to the treatments. The cells originated from a culture based on a mixture of 1/10 L1 medium and cells grown in full medium. At the end of the experiment (day 8), $\mathrm{pH}$ was measured and subsamples for cell enumeration, nutrients and DA analyses were taken as described above. The copepodites were collected by sieving the total content through a $200 \mu \mathrm{m}$ sieve to remove phytoplankton and fecal pellets. The copepodites were rinsed with $0.22 \mu \mathrm{m}$ filtered seawater, and individually transferred to a $\mathrm{GF} / \mathrm{F}$ filter and stored at $-20{ }^{\circ} \mathrm{C}$.

\subsection{Induction Experiment in Filtrate Water}

Filtrate water was prepared by placing $>70$ actively swimming copepodites into $0.22 \mu \mathrm{m}(\sim 6 \mathrm{~L})$ filtered seawater with a unialgal culture of Thalassiosira sp. for $24 \mathrm{~h}$. The copepodites and the fecal pellets were removed by using a $50 \mu \mathrm{m}$ sieve and the cells of Thalassiosira sp. removed by filtering 
through a $0.22 \mu \mathrm{m}$ filter. Experimental flasks with an initial cell concentration of 4000 cells $\mathrm{mL}^{-1}$ of $P$. seriata, was prepared using this filtrated water using $720 \mathrm{~mL}$ polystyrene flasks. The experiment was conducted in four replicates and three controls and run on the plankton wheel simultaneously for $39 \mathrm{~h}$ with the grazing experiment (Section 4.3).

\subsection{Microscopy}

For enumeration of the algal cells, a Sedgewick-Rafter chamber and an inverted light microscope (Olympus CKX31 at a 100× magnification). A minimum of 400 cells were counted. Fecal pellets were counted using a stereo microscope (Reichter at $16 \times$ magnification) and width $\times$ length of the fecal pellets was measured using 40× magnification. For measurements of Calanus and Pseudo-nitzschia see Sections 4.1.1 and 4.1.2.

\subsection{Statistical Analyses}

Normal distribution of data was tested using a Shapiro-Wilk test and homogeneity of variances applying Levene's test. The differences over time within each treatment were tested by repeated-measures ANOVA (RM ANOVA) and post hoc analysis tested using Holms-Sidak adjustments. Differences between means were tested using one-way ANOVA, a $t$-test or a paired $t$-test. If the data set did not pass the assumption of normal distribution, a Mann-Whitney U-test or a Kruskall-Wallis test were used. For the nutrients measurements in Table 2 and Supplementary Table S1, the statistical analyses were conducted with paired $t$-test between the start and end, and $t$-test between the control end and the treatments end. Results given as * = significant difference from control start an ** for significant difference from the control end. The level of significance used was 0.05 .

\section{Acknowledgments}

We thank the Arctic station in Qeqertarsuaq, Greenland and the scientific leader Ole Stecher for providing excellent research facilities and help in many ways. We thank Abel Brand and Johannes Mølgaard for assistance with collecting samples, Lis Munk Frederiksen for fieldwork and assistance with the experiments. We thank Wolfgang Drebing for sample extraction and toxin measurements and Dorottya Sarolta Wágner for assisting with spectrophotometric measurements. Funding was provided by the Carlsberg Foundation (2012_01_0556) and grant DFF-1323-00258 from the Danish Research Council to NL and a grant given from: Botanisk forening; Konto af 1988 for botaniske mikroorganismeforskning to $\mathrm{SH}$.

\section{Author Contributions}

Sara Harðardóttir: Designed the study, carried out the experiments, enumerated the samples, analysed the data and wrote the manuscript.

Marina Pančić: Carried out the experiments, enumerated the samples, analysed the data and revised the manuscript.

Anna Tammilehto: Designed the study, discussed the results and revised the manuscript.

Bernd Krock: Performed toxin analyses and revised the manuscript. 
Eva Friis Møller: Performed the nutrient analyses and revised the manuscript.

Torkel Gissel Nielsen: Discussed the results, revised the manuscript.

Nina Lundholm: Designed the study, carried out the experiments, discussed the results and revised the manuscript.

\section{Conflicts of Interest}

The authors declare no conflict of interest.

\section{References}

1. Quilliam, M.A.; Wright, J.L.C. The amnesic shellfish poisoning mystery. Anal. Chem. 1989, 61, 1053A-1060A.

2. Perl, T.M.; Bedard, L.; Kosatsky, T.; Hockin, J.C.; Todd, E.C.D.; Remis, R.S. An outbreak of toxic encephalopathy caused by eating mussels contaminated with domoic acid. N. Engl. J. Med. 1990, 322, 1775-1780.

3. Fritz, L.; Quilliam, M.A.; Wright, J.L.C.; Beale, A.M.; Work, T.M. An outbreak of domoic acid poisoning attributed to the pennate diatom Pseudo-nitzschia australis. J. Phycol. 1992, 28, 439-442.

4. Fire, S.E.; Wang, Z.H.; Berman, M.; Langlois, G.W.; Morton, S.L.; Sekula-Wood, E.; Benitez-Nelson, C.R. Trophic transfer of the harmful algal toxin domoic acid as a cause of death in a Minke whale (Balaenoptera acutorostrata) stranding in Southern California. Aquat. Mamm. 2010, 36, 342-350.

5. Trainer, V.L.; Bates, S.S.; Lundholm, N.; Thessen, A.E.; Cochlan, W.P.; Adams, N.G.; Trick, C.G. Pseudo-nitzschia physiological ecology, phylogeny, toxicity, monitoring and impacts on ecosystem health. Harmful Algae 2012, 14, 271-300.

6. Smida, D.B.; Lundholm, N.; Kooistra, W.; Sahraoui, I.; Ruggiero, M.V.; Kotaki, Y.; Ellegaard, M.; Lambert, C.; Mabrouk, H.H.; Hlaili, A.S. Morphology and molecular phylogeny of Nitzschia bizertensis sp. Nov. A new domoic acid producer. Harmful Algae 2014, 32, 49-63.

7. Costa, P.R.; Garrido, S. Domoic acid accumulation in the sardine Sardina pilchardus and its relationship to Pseudo-nitzschia diatom ingestion. Mar. Ecol. Prog. Ser. 2004, 284, 261-268.

8. Wohlgeschaffen, G.D.; Mann, K.H.; Rao, D.V.S.; Pocklington, R. Dynamics of the phycotoxin domoic acid accumulation and excretion in 2 commercially important bivalves. J. Appl. Phycol. 1992, 4, 297-310.

9. Maneiro, I.; Iglesias, P.; Guisande, C.; Riveiro, I.; Barreiro, A.; Zervoudaki, S.; Graneli, E. Fate of domoic acid ingested by the copepod Acartia clausi. Mar. Biol. 2005, 148, 123-130.

10. Turner, J.T. Planktonic marine copepods and harmful algae. Harmful Algae 2014, 32, 81-93.

11. Lelong, A.; Hegaret, H.; Soudant, P.; Bates, S.S. Pseudo-nitzschia (Bacillariophyceae) species, domoic acid and amnesic shellfish poisoning: Revisiting previous paradigms. Phycologia 2012, $51,168-216$.

12. Hansen, L.R.; Soylu, S.Í.; Kotaki, Y.; Moestrup, Ø.; Lundholm, N. Toxin production and temperature-induced morphological variation of the diatom Pseudo-nitzschia seriata from the Arctic. Harmful Algae 2011, 10, 689-696. 
13. Lundholm, N.; Skov, J.; Pocklington, R.; Moestrup, Ø. Domoic acid, the toxic amino-acid responsible for amnesic shellfish poisoning, now in Pseudonitzschia seriata (Bacillariophyceae) in Europe. Phycologia 1994, 33, 475-478.

14. Lincoln, J.A.; Turner, J.T.; Bates, S.S.; Leger, C.; Gauthier, D.A. Feeding, egg production, and egg hatching success of the copepods Acartia tonsa and Temora longicornis on diets of the toxic diatom Pseudo-nitzschia multiseries and the non-toxic diatom Pseudo-nitzschia pungens. Hydrobiologia 2001, 453, 107-120.

15. Leandro, L.F.; Teegarden, G.J.; Roth, P.B.; Wang, Z.; Doucette, G.J. The copepod Calanus finmarchicus: A potential vector for trophic transfer of the marine algal biotoxin, domoic acid. J. Exp. Mar. Biol. Ecol. 2010, 382, 88-95.

16. Tester, P.A.; Pan, Y.; Douchette, G.J. Accumulation of domoic acid activity in copepods. In Harmful and Toxic Algal Blooms 2000; Hallegraeff, G.M., Blackburn, S.I., Bolch, C.J., Lewis, R.J., Eds.; Intergovernmental Oceanographic Commission of UNESCO: Paris, France, 2001; pp. 401-404.

17. Windust, A. The Responses of Bacteria, Microalgae, and Zooplankton to the Diatom Nitzschia pungens f. Multiseries and Its Toxic Metabolite Domoic Acid. M.S. Thesis, Dalhousie University, Halifax, Canada, 1992.

18. Tammilehto, A.; Nielsen, T.G.; Krock, B.; Møller, E.F.; Lundholm, N. Calanus spp.-vectors for the biotoxin, domoic acid, in the Arctic marine ecosystem? Harmful Algae 2012, 20, 165-174.

19. Bargu, S.; Marinovic, B.; Mansergh, S.; Silver, M.W. Feeding responses of krill to the toxin-producing diatom Pseudo-nitzschia. J. Exp. Mar. Biol. Ecol. 2003, 284, 87-104.

20. Tammilehto, A.; Nielsen, T.G.; Krock, B.; Møller, E.F.; Lundholm, N. Induction of domoic acid production in the toxic diatom Pseudo-nitzschia seriata by calanoid copepods. Aquat. Toxicol. 2015, 159, 52-61.

21. Fehling, J.; Davidson, K.; Bolch, C.J.; Bates, S.S. Growth and domoic acid production by Pseudo-nitzschia seriata (Bacillariophyceae) under phosphate and silicate limitation. J. Phycol. 2004, 40, 674-683.

22. Bates, S.S.; Worms, J.; Smith, J.C. Effects of ammonium and nitrate on growth and domoic acid production by Nitzschia pungens in batch culture. Can. J. Fish. Aquat. Sci. 1993, 50, 1248-1254.

23. Lundholm, N.; Hansen, P.J.; Kotaki, Y. Effect of $\mathrm{pH}$ on growth and domoic acid production by potentially toxic diatoms of the genera Pseudo-nitzschia and Nitzschia. Mar. Ecol. Prog. Ser. 2004, 273, 1-15.

24. Selander, E.; Thor, P.; Toth, G.; Pavia, H. Copepods induce paralytic shellfish toxin production in marine dinoflagellates. Proc. R. Soc. B 2006, 273, 1673-1680.

25. Selander, E.; Cervin, G.; Pavia, H. Effects of nitrate and phosphate on grazer-induced toxin production in Alexandrium minutum. Limnol. Oceanogr. 2008, 53, 523-530.

26. Long, J.D.; Smalley, G.W.; Barsby, T.; Anderson, J.T.; Hay, M.E. Chemical cues induce consumer-specific defenses in a bloom-forming marine phytoplankton. Proc. Natl. Acad. Sci. USA 2007, 104, 10512-10517.

27. Lundgren, V.; Granéli, E. Grazer-induced defence in Phaeocystis globosa (Prymnesiophyceae): Influence of different nutrient conditions. Limnol. Oceanogr. 2010, 55, 1965-1976. 
28. Tande, K.S. Ecological investigations on the zooplankton community of Balsfjorden, northern Norway: Generation cycles, and variations in body-weight and body content of carbon and nitrogen related to overwintering and reproduction in the copepod Calanus finmarchicus (Gunnerus). J. Exp. Mar. Biol. Ecol. 1982, 62, 129-142.

29. Hansen, B.W.; Nielsen, T.G.; Levinsen, H. Plankton community structure and carbon cycling on the western coast of Greenland during the stratified summer situation. III. Mesozooplankton. Aquat. Microb. Ecol. 1999, 16, 233-249.

30. Nielsen, T.G.; Hansen, B. Plankton community structure and carbon cycling on the western coast of Greenland during and after the sedimentation of a diatom bloom. Mar. Ecol. Prog. Ser. 1995, 125, 239-257.

31. Madsen, S.D.; Nielsen, T.G.; Hansen, B.W. Annual population development and production by Calanus finmarchicus, C. glacialis and C. hyperboreus in Disko bay, western Greenland. Mar. Biol. 2001, 139, 75-93.

32. Wohlrab, S.; Iversen, M.H.; John, U. A molecular and co-evolutionary context for grazer induced toxin production in Alexandrium tamarense. PLoS ONE 2010, 5, e15039.

33. Whyte, J.N.C.; Townsend, L.D.; Ginther, N.G. Fecundity, toxin and trophic levels of the rotifer Brachionus plicatilis fed Pseudo-nitzschia pungens $f$. Multiseries. Available online: http://diatom. myspecies.info/node/331 (accessed on 23 May 2015).

34. Meyer, B.; Irigoien, X.; Graeve, M.; Head, R.N.; Harris, R.P. Feeding rates and selectivity among nauplii, copepodites and adult females of Calanus finmarchicus and Calanus helgolandicus. Helgoland Mar. Res. 2002, 56, 169-176.

35. Koski, M.; Wexels Riser, C. Post-bloom feeding of Calanus finmarchicus copepodites: Selection for autotrophic versus heterotrophic prey. Mar. Biol. Res. 2006, 2, 109-119.

36. Huntley, M.; Sykes, P.; Rohan, S.; Marin, V. Chemically-mediated rejection of dinoflagellate prey by the copepods Calanus pacificus and Paracalanus parvus-mechanism, occurrence and significance. Mar. Ecol. Prog. Ser. 1986, 28, 105-120.

37. Sykes, P.F.; Huntley, M.E. Acute physiological reactions of Calanus pacificus to selected dinoflagellates - direct observations. Mar. Biol. 1987, 94, 19-24.

38. Bergkvist, J.; Selander, E.; Pavia, H. Induction of toxin production in dinoflagellates: The grazer makes a difference. Oecologia 2008, 156, 147-154.

39. Frost, B.W. Effects of size and concentration of food particles on feeding behavior of marine planktonic copepod Calanus pacificus. Limnol. Oceanogr. 1972, 17, 805-815.

40. Round, F.E.; Crawford, R.M.; Mann, D.G. The Diatoms: Biology \& Morphology of the Genera; Cambridge University Press: London, UK, 1990.

41. Levinsen, H.; Turner, J.T.; Nielsen, T.G.; Hansen, B.W. On the trophic coupling between protists and copepods in arctic marine ecosystems. Mar. Ecol. Prog. Ser. 2000, 204, 65-77.

42. Shaw, B.A.; Andersen, R.J.; Harrison, P.J. Feeding deterrent and toxicity effects of apo-fucoxanthinoids and phycotoxins on a marine copepod (Tigriopus californicus). Mar. Biol. 1997, 128, 273-280.

43. Bargu, S.; Lefebvre, K.; Silver, M.W. Effect of dissolved domoic acid on the grazing rate of krill Euphausia pacifica. Mar. Ecol. Prog. Ser. 2006, 312, 169-175. 
44. Colin, S.P.; Dam, H.G. Comparison of the functional and numerical responses of resistant versus non-resistant populations of the copepod Acartia hudsonica fed the toxic dinofiagellate Alexandrium tamarense. Harmful Algae 2007, 6, 875-882.

45. Colin, S.P.; Dam, H.G. Latitudinal differentiation in the effects of the toxic dinoflagellate Alexandrium spp. On the feeding and reproduction of populations of the copepod Acartia hudsonica. Harmful Algae 2002, 1, 113-125.

46. Colin, S.P.; Dam, H.G. Testing for resistance of pelagic marine copepods to a toxic dinoflagellate. Evol. Ecol. 2004, 18, 355-377.

47. Jiang, X.; Lonsdale, D.J.; Gobler, C.J. Rapid gain and loss of evolutionary resistance to the harmful dinoflagellate Cochlodinium polykrikoides in the copepod Acartia tonsa. Limnol. Oceanogr. 2011, 56, 947-954.

48. Zheng, Y.; Dam, H.G.; Avery, D.E. Differential responses of populations of the copepod Acartia hudsonica to toxic and nutritionally insufficient food algae. Harmful Algae 2011, 10, 723-731.

49. Bricelj, V.M.; Connell, L.; Konoki, K.; MacQuarrie, S.P.; Scheuer, T.; Catterall, W.A.; Trainer, V.L. Sodium channel mutation leading to saxitoxin resistance in clams increases risk of PSP. Nature 2005, 434, 763-767.

50. Hygum, B.H.; Rey, C.; Hansen, B.W.; Tande, K. Importance of food quantity to structural growth rate and neutral lipid reserves accumulated in Calanus finmarchicus. Mar. Biol. 2000, 136, 1057-1073.

51. Jónasdóttir, S.H. Lipid content of Calanus finmarchicus during overwintering in the Faroe-Shetland Channel. Fish. Oceanogr. 1999, 8, 61-72.

52. Niehoff, B. The effect of food limitation on gonad development and egg production of the planktonic copepod Calanus finmarchicus. J. Exp. Mar. Biol. Ecol. 2004, 307, 237-259.

53. Cushing, D.H.; Humphrey, G.F.; Banse, K.; Laevastu, T. Report of the committee on terms and equivalents. Rapp. P.-V. Reun. Cons. Int. Explor. Mer. 1958, 144, 15-16.

54. Swalethorp, R.; Kjellerup, S.; Dünweber, M.; Nielsen, T.G.; Møller, E.F.; Rysgaard, S.; Hansen, B.W. Grazing, egg production, and biochemical evidence of differences in the life strategies of Calanus finmarchicus, C. glacialis and C. hyperboreus in Disko bay, western Greenland. Mar. Ecol. Prog. Ser. 2011, 429, 125-144.

55. Harris, R.P.; Wiebe, P.H.; Lenz, J.; Skjoldal, H.R.; Huntley, M. Zooplankton Methodology Manual; Elsevier Academic Press: Beijing, China, 2005.

56. Thor, P.; Wendt, I. Functional response of carbon absorption efficiency in the pelagic calanoid copepod Acartia tonsa Dana. Limnol. Oceanogr. 2010, 55, 1779-1789.

57. Selander, E.; Kubanek, J.; Hamberg, M.; Andersson, M.X.; Cervin, G.; Pavia, H. Predator lipids induce paralytic shellfish toxins in bloom-forming algae. Proc. Natl. Acad. Sci. USA 2015, 112, 6395-6400.

58. Trimborn, S.; Lundholm, N.; Thoms, S.; Richter, K.U.; Krock, B.; Hansen, P.J.; Rost, B. Inorganic carbon acquisition in potentially toxic and non-toxic diatoms: The effect of $\mathrm{pH}$-induced changes in seawater carbonate chemistry. Physiol. Plant. 2008, 133, 92-105.

59. Howard, M.D.A.; Cochlan, W.P.; Ladizinsky, N.; Kudela, R.M. Nitrogenous preference of toxigenic Pseudo-nitzschia australis (Bacillariophyceae) from field and laboratory experiments. Harmful Algae 2007, 6, 206-217. 
60. Heisterkamp, I.M.; Schramm, A.; de Beer, D.; Stief, P. Nitrous oxide production associated with coastal marine invertebrates. Mar. Ecol. Prog. Ser. 2010, 415, 1-9.

61. Koops, H.-P.; Purkhold, U.; Pommerening-Roeser, A.; Timmermann, G.; Wagner, M. The Lithoautotrophic Ammonia-Oxidizing Bacteria; Springer: New York, NY, USA, 2006; pp. 778-811.

62. Stief, P. University of Southern Denmark, Odense, Denmark. Personal communication, 2015.

63. Anderson, C.R.; Brzezinski, M.A.; Washburn, L.; Kudela, R. Circulation and environmental conditions during a toxigenic Pseudo-nitzschia australis bloom in the Santa Barbara Channel, california. Mar. Ecol. Prog. Ser. 2006, 327, 119-133.

64. Schnetzer, A.; Miller, P.E.; Schaffner, R.A.; Stauffer, B.A.; Jones, B.H.; Weisberg, S.B.; DiGiacomo, P.M.; Berelson, W.M.; Caron, D.A. Blooms of Pseudo-nitzschia and domoic acid in the San Pedro Channel and Los Angeles harbor areas of the Southern California Bight, 2003-2004. Harmful Algae 2007, 6, 372-387.

65. Trainer, V.L.; Hickey, B.M.; Lessard, E.J.; Cochlan, W.P.; Trick, C.G.; Wells, M.L.; MacFadyen, A.; Moore, S.K. Variability of Pseudo-nitzschia and domoic acid in the Juan de Fuca eddy region and its adjacent shelves. Limnol. Oceanogr. 2009, 54, 289-308.

66. Trainer, V.L.; Wells, M.L.; Cochlan, W.P.; Trick, C.G.; Bill, B.D.; Baugh, K.A.; Beall, B.F.; Herndon, J.; Lundholm, N. An ecological study of a massive bloom of toxigenic Pseudo-nitzschia cuspidata off the Washington state coast. Limnol. Oceanogr. 2009, 54, 1461-1474.

67. Marchetti, A.; Trainer, V.L.; Harrison, P.J. Environmental conditions and phytoplankton dynamics associated with Pseudo-nitzschia abundance and domoic acid in the Juan de Fuca eddy. Mar. Ecol. Prog. Ser. 2004, 281, 1-12.

68. Lundholm, N.; Andersen, P.; Jorgensen, K.; Thorbjornsen, B.R.; Cembella, A.; Krock, B. Domoic acid in danish blue mussels due to a bloom of Pseudo-nitzschia seriata. Harmful Algae News 2005, 29, 8-10.

69. Fehling, J.; Green, D.H.; Davidson, K.; Bolch, C.J.; Bates, S.S. Domoic acid production by Pseudo-nitzschia seriata (Bacillariophyceae) in Scottish waters. J. Phycol. 2004, 40, 622-630.

70. Bates, S.S.; Léger, C.; White, J.M.; MacNair, N.; Ehrman, J.M.; Levasseur, M.; Couture, J.Y.; Gagnon, R.; Bonneau, F.; Michaud, S.; et al. Pennate diatom Pseudo-nitzschia seriata; domoic acid production causes spring closures of shellfish harvesting for the first time in the southern gulf of St. Lawrence, eastern Canada. In Proceedings of the 17th International Diatom Symposium, Ottawa, Canada, 25-31 August 2002.

71. Trainer, V.L.; Adams, N.G.; Bill, B.D.; Stehr, C.M.; Wekell, J.C.; Moeller, P.; Busman, M.; Woodruff, D. Domoic acid production near California coastal upwelling zones, June 1998. Limnol. Oceanogr. 2000, 45, 1818-1833.

72. Scholin, C.A.; Gulland, F.; Doucette, G.J.; Benson, S.; Busman, M.; Chavez, F.P.; Cordaro, J.; DeLong, R.; De Vogelaere, A.; Harvey, J.; et al. Mortality of sea lions along the central California coast linked to a toxic diatom bloom. Nature 2000, 403, 80-84.

73. Hasle, G.R.; Lundholm, N. Pseudo-nitzschia seriata f. obtusa (Bacillariophyceae) raised in rank based on morphological, phylogenetic and distributional data. Phycologia 2005, 44, 608-619.

74. Guillard, R.R.L.; Hargraves, P.E. Stichochrysis immobilis is a diatom, not a chyrsophyte. Phycologia 1993, 32, 234-236. 
75. Hansen, P.J.; Bjornsen, P.K.; Hansen, B.W.; Bjørnsen, P.K. Zooplankton grazing and growth: Scaling within the 2-2000 $\mu \mathrm{m}$ body size range. Limnol. Oceanogr. 1997, 42, 687-704.

76. Corner, E.D.S.; Newell, B.S. On nutrition and metabolism of zooplankton 4 forms of nitrogen excreted by Calanus. J. Mar. Biol. Assoc. UK 1967, 47, 113-120.

77. Hansen, H.P.; Koroleff, F. Determination of nutrients. In Methods of Seawater Analysis; Wiley-VCH Verlag GmbH: Weinheim, Germany, 2007; pp. 159-228.

78. Tang, K.W. Grazing and colony size development in Phaeocystis globosa (Prymnesiophyceae): The role of a chemical signal. J. Plankton Res. 2003, 25, 831-842.

(C) 2015 by the authors; licensee MDPI, Basel, Switzerland. This article is an open access article distributed under the terms and conditions of the Creative Commons Attribution license (http://creativecommons.org/licenses/by/4.0/). 